\title{
Exploration of Innovation Ability Training Strategy for Students Majoring in Tourism Management Major
}

\author{
Yeling Feng \\ Sichuan TOP IT Vocational Institute, Chengdu Sichuan, 611743, China
}

Keywords: College, Tourism management specialty, Innovation ability training, Strategy

\begin{abstract}
Tourism management talents should not merely own solid professional knowledge and application skills, but also have certain innovation ability and contribute to tourism service and development. Innovation ability training of tourism management talents needs to depend on the training of tourism management specialty except students' efforts. Thus, contemporary education needs to pay attention to cultivating students' innovation ability in college tourism management specialty. This paper will simply analyze students' innovation ability training strategy of college tourism management specialty.
\end{abstract}

\section{Introduction}

Tourism development not just needs tourism management personnel to own basic professional skills and certain innovation spirit. In this way, more originalities and approaches can be offered for development of tourism industry. Hence, colleges must advance with the times and put students' innovation ability training on the agenda in tourism management teaching.

\section{Necessity of Innovation Ability Training for Students Majoring in Tourism Management}

\section{Conform to Era Development Pace}

As economy enters global development, many changes have taken place in society, science, technology and culture in China. People's life style and consumption idea also alter continuously. In recent years, tourism industry has been pursued by people. By this chance, tourism launches multiple tourism products to meet traveling needs of more people ${ }^{[1]}$. It is found through investigation of tourism industry that people's life style and consumption idea exert great influence on the service mode of tourism activity. The colleges of tourism as the bases for tourism management talent training must keep pace with the era and regard social development as the orientation in talent training process to cultivate high-quality talents with certain innovation ability. The students majoring in tourism management can accord with social development and diversified tourism demands only through continuously enriching their knowledge, exploring and innovating.

\section{Meet Talent Demand of Tourism Industry}

Tourism industry is an industry with strong service property. Through development for many years, traditional tourism services have basically reached saturation. As the competition of tourism industry increases and people's consumption concept alters, tourism industry is forced to innovate continuously so as to develop more tourism products and services and satisfy diversified tourism demands. Hence, in order to stand out in fierce competitions, tourism-related enterprises must know customers' demand changes, adjust tourism scheme, design tourism products and service items according to tourists' different needs ${ }^{[2]}$. These requirements must be supported by the talents with high quality, skills and innovation ability. Therefore, it is very necessary to train innovation ability of students majoring in tourism management. 


\section{Factors Influencing Innovation Ability Training of Students Majoring in Tourism Management}

\section{Backward Educational Thought}

Under the influence of traditional teaching thought, both colleges and teachers fail to pay sufficient attention to innovation ability training of students majoring in tourism management. Examination-oriented education is deep-rooted in the mind of teachers and students. Most colleges pay attention to theory and ignore practice. Theoretical courses occupy a large proportion, while practical courses are few. Even some colleges cancel practical courses ${ }^{[3]}$. In such case, students are naturally difficult to form favorable practical application ability. Although some colleges set corresponding practical training course and training base in the disguise of students' innovation ability training, they muddle through the work in practical teaching process. Students cannot train innovation idea and innovation spirit through practical courses so that practical courses become a mere formality. Besides, there is no guidance of corresponding courses and teachers, and students are difficult to innovate consciously.

For students, innovation ability training should be based on clear innovation awareness. Teachers must establish innovation awareness for students, mobilize students' innovation interest, then discover practical problems on the basis of mastering relevant basic knowledge and solve problems by the knowledge learned un the process of continuous adaptation and exploration. But at present, many students majoring in tourism management have no innovation awareness. Most students are fond of being content with things as they are, and consider as long as they are able to pass the examination smoothly and gain the graduation certificate, they complete the learning. Such negative thought seriously hinders students' innovation awareness training and innovation ability exertion.

\section{Deficiency in Teaching Mode}

Course setting is unreasonable

Innovation ability training needs to be supported by professional basic knowledge. Professional knowledge is mainly learned by students in classroom teaching. Students master certain basic knowledge through learning specialized courses, then explore and study knowledge and apply the knowledge in practice so as to improve innovation ability. China's tourism industry develops in recent years. Tourism teaching time is short, so tourism management course setting in most colleges is not perfect and many problems exist. For instance, currently, most tourism courses are set on the basis of basic theoretical knowledge about tourism and rarely involve other inter-disciplines. Students' scope of knowledge mainly concentrates in tourism specialty and is difficult to expand. This seriously hinders expansion of students' thinking and view so that students' innovation ability training is restricted. In such course setting, students only learn the knowledge of tourism specialty and fail to dabble in other humanistic knowledge. Such narrow and inane knowledge network cannot show their unique profession in all-round cultural environment. This not just limits students' subjective initiative, but curbs students' independent innovation awareness so that students are difficult to adapt the demand of contemporary society for tourism innovation talents.

\section{Unreasonable Application of Teaching Method}

Course teaching is a major channel for students to learn professional knowledge, so teachers must conduct classroom education well, and adopt rational teaching method to attract students' attention and improve students' learning efficiency. Teachers' teaching method plays a significant role in classroom teaching and can also be called the soul of teaching. If teachers' teaching method is not rational, students will lose learning interest and affect students' learning of professional knowledge, let alone innovation ability training. Teachers' subjectivity is stressed in traditional teaching way. Teachers take textbooks as the main teaching basis and regard classroom as the main teaching place. Thus, students' thinking and thought are restricted. In addition, teachers' teaching modes are very single. Teachers mostly give lecture on the platform and students passively listen. No matter whether emergency situation occurs in classroom, teachers adopt the same teaching mode and lack flexibility ${ }^{[4]}$. Such obsolete and single teaching mode may easily result in students' dislike. Moreover, such passive infusion mode will make students generate inert thought, and students cannot form 
independent thinking ability which is the precondition of innovation ability training. Hence, it is difficult to effectively train students' innovation ability in such training mode.

Lack of Effective Practical Course Arrangement

Practical teaching expands and tests theoretical teaching, which is also the foundation of students' innovation ability training. Tourism management specialty has strong practicalness, so teachers should fully utilize practical courses and pay attention to students' innovative thinking and innovation ability training in practical work. But, practical courses of students majoring in college tourism management are not reasonable enough in the design of practical link and lack necessary management and control. For theoretical courses, management of practical courses is complex. The relationship between teachers and students should be coordinated in practical courses. Meanwhile, external social relations are also involved, and the bases for practice are not fixed. Thus, it is very hard to uniformly manage students. Some colleges attach importance to theory in course arrangement and overlook the significance of practical courses. Hence, there is short of rational arrangement of practice link in courses. Students cannot gain effective practical training in the college. For instance, colleges lack feasible operation criteria in teaching content arrangement and practical course arrangement so that practical teaching setting lacks norms and control. Colleges cannot meet substituted post exercitation requirements of all students. Even if some students participate in substituted post exercitation, they cannot gain whole-process guidance of professional personnel in the internship process.

\section{Unreasonable Teaching Evaluation Factors}

Teaching evaluation mechanism is also a major factor influencing students' innovation ability. At present, the evaluation mechanism of college tourism specialty is mainly based on examination scores. In examination paper design, tourism-related basic knowledge is the key point, and rarely involves students' innovation ability training or such aspect is completely blank. Such evaluation mechanism is to the disadvantage of students' digestion of knowledge and innovation ability training. Furthermore, seeing from teachers' evaluation mechanism, there are also some defects. Generally, colleges mainly evaluate teachers from teachers' achievements in scientific research, which causes that teachers are unwilling to spend their energy on course reform and innovation ability training, but muddle along in teaching and make more efforts on scientific research. Unreasonable evaluation mechanism makes students’ innovation ability training greatly restricted.

\section{Innovation Ability Training Strategy for Students Majoring in Tourism Management}

\section{To Improve Cognition of Innovation Ability Training}

To boost students' innovation ability, traditional teaching concept must be transformed. Students' innovation ability training should be valued in teaching. Based on teaching students basic knowledge, students should guide students to cultivate innovation awareness and innovative thinking so that students can form innovation thought in their mind. In this way, students can innovate through application and fusion of basic knowledge in practical work. Teachers of college tourism management specialty must have correct cognition of talents of tourism specialty, cultivate students according to their features, establish student-oriented idea and pay attention to training professional skills and innovation ability. At the same time, students also should transform learning idea, dare to question and ask questions in study and expand their thinking and scope of knowledge. In case of problems in study or life, students should dare to encounter them and cultivate the habit of innovation ability problem solving. Through persistence and practice for a long time, students can improve their innovative thinking and problem solving ability. Additionally, students should actively participate in learning, be good at analyzing and summarizing, look up tourism-related works in their spare time, absorb essential thinking and thought, practice and improve their innovative thinking and innovation ability through continuous internalization and practice ${ }^{[5]}$.

\section{To Construct Perfect Teaching System}

To cultivate all-round high-quality talents in tourism management, college tourism management specialty must adjust teaching system, optimize course structure, increase class hours of practical courses and transform professional teaching course to comprehensive teaching course. In teaching, 
colleges may adopt flexible teaching mode. After students finish basic tourism teaching, colleges may allow them to choose the courses according to their interests and needs so that students can further learn their favorite specialty and courses. In this way, students will take delight in learning and lay a foundation for innovation ability training. Meanwhile, in each course system for students to choose, perfect knowledge structure is required to fully train students' innovation ability. Tourism industry involves a lot of knowledge, so relevant courses may be set in tourism course setting. These courses may be set to optimal courses. Students may choose these optimal courses and complete knowledge expansion according to their needs and hobbies. Through learning other specialties, students' scope of knowledge is expanded, and their multiple thinking modes are also trained so that they can benefit in future learning and work. Besides, colleges may provide some innovative courses according to current situation of tourism market so that students can apply what they have learned. Such mode may be used to encourage students for innovation and help them establish innovation confidence.

\section{To Improve Teaching Method}

Teaching method is the soul of classroom teaching. To train students' innovative thinking and innovation ability, original teaching method must be improved. Traditional teaching method is too old-fashioned and single and difficult to motivate their learning interest so that students suffer limits in basic knowledge mastery and innovation ability promotion. Thus, teachers must abandon traditional teaching method and set teaching situation in teaching. Teachers may set scenario simulation and students conduct role play. Such method can help students to improve their learning interest, and such classroom teaching also increases students' interactions so that students can take active part in teaching. Additionally, teachers may encourage students to design situations according to teaching contents and perform. In this way, students can not just improve classroom efficiency, but also effectively train students' innovation ability. Besides, teachers can utilize multimedia to play cases, require students to carry out case analysis through case study, found out the useful points and shortcomings in the cases and perfect the cases. Such open teaching mode can motivate students' learning interest, mobilize students' thinking and improve their innovation ability on the basis of independently solving problems.

\section{Conclusions}

In conclusion, with economic development and the change in people's consumption concept, tourism industry must innovate in order to remain invincible in fierce tourism market competitions. Colleges as the training bases of tourism management talents must advance with the times, change teaching thought, perfect teaching system, improve teaching method and train all-round tourism management talents with sufficient knowledge, high quality and innovation ability.

\section{References}

[1] Wang Yuan, On Approaches of Innovation Ability Training for Students Majoring in Tourism Management. Journal of Sichuan Tourism University, 2015(4):77-80.

[2] Wang Lu, Discussion on Diversified Practical Teaching Mode for Tourism Management Specialty. China University Teaching, 2012(7):79-80.

[3] Zheng Yu, Significance of Studying Innovation Ability Training for Undergraduates Majoring in Tourism Management. China Education Innovation Herald, 2014(26):30-31.

[4] Sun Yonglong, Construction of Practical Teaching System of Tourism Management Based on Innovation Ability Training. Journal of the Northwest Adult Education, 2013(6):70-73.

[5] Gao Yuling, Innovation Ability Training Thought of College Tourism Talents. Science Guide, 2014(z1):187-187,188. 